\title{
Diode Laser for Laryngeal Surgery: a Systematic Review
}

\author{
Helena Hotz Arroyo ${ }^{1}$ Larissa Neri ${ }^{1} \quad$ Carina Yuri Fussuma ${ }^{1}$ Rui Imamura ${ }^{1}$ \\ ${ }^{1}$ Department of Otorhinolaryngology, Hospital das Clínicas, School of \\ Medicine, Universidade de São Paulo, São Paulo, Brazil

\begin{abstract}
Address for correspondence Helena Hotz Arroyo, MD, Universidade de São Paulo, Avenida Doutor Eneas de Carvalho Aguiar 155, 60 andar sala 6167, Sao Paulo, Brazil (e-mail: helenaharroyo@hotmail.com).
\end{abstract}

Int Arch Otorhinolaryngol 2016;20:172-179.

\begin{abstract}
Keywords

- diode laser

- larynx

- vocal fold

- glottis

- laryngeal neoplasms

Introduction The diode laser has been frequently used in the management of laryngeal disorders. The portability and functional diversity of this tool make it a reasonable alternative to conventional lasers. However, whether diode laser has been applied in transoral laser microsurgery, the ideal parameters, outcomes, and adverse effects remain unclear.

Objective The main objective of this systematic review is to provide a reliable evaluation of the use of diode laser in laryngeal diseases, trying to clarify its ideal parameters in the larynx, as well as its outcomes and complications.

Data Synthesis We included eleven studies in the final analysis. From the included articles, we collected data on patient and lesion characteristics, treatment (diode laser's parameters used in surgery), and outcomes related to the laser surgery performed. Only two studies were prospective and there were no randomized controlled trials. Most of the evidence suggests that the diode laser can be a useful tool for treatment of different pathologies in the larynx. In this sense, the parameters must be set depending on the goal (vaporization, section, or coagulation) and the clinical problem.

Conclusion: The literature lacks studies on the ideal parameters of the diode laser in laryngeal surgery. The available data indicate that diode laser is a useful tool that should be considered in laryngeal surgeries. Thus, large, well-designed studies correlated with diode compared with other lasers are needed to better estimate its effects.
\end{abstract}

\section{Introduction}

Lasers have been used in laryngeal surgeries since 1972, when Strong and Jako first reported the use of carbon dioxide laser $\left(\mathrm{CO}_{2}\right)$ in the human larynx. ${ }^{1}$ Despite initial criticism, endoscopic laser treatments have achieved universal acceptance and been successfully used in endolaryngeal microsurgery (EMS). ${ }^{2}$ Most of the laser procedures involve either excision or tissue vaporization, depending on the interaction between the wavelength $(\lambda)$ and the chromophores of the tissue. For years, the $\mathrm{CO}_{2}(\lambda=10600 \mathrm{~nm})$ seemed to be the preferred laser for transoral laser microsurgery due to its precise cut, ${ }^{3}$ given that it is better absorbed by water. However, there are some disadvantages of the $\mathrm{CO}_{2}$ device, namely, its straight line beam delivery from surgical microscope, narrow penetration depth to tissue, difficult transportation, and increased cost. These drawbacks favored the study and application of other wavelengths in larynx, such as Thulium YAG $(\lambda=2000 \mathrm{~nm})$, Nd:YAG (neodimium:yttriumaluminum-garnet $-\lambda=1064 \mathrm{~nm})$, diode $(\lambda=805-980 \mathrm{~nm})$, PDL (pulsed dye laser $-\lambda=585 \mathrm{~nm}$ ) and KTP (potassium titanyl phosphate $-\lambda=532 \mathrm{~nm})^{3,4}$

The diode laser has excellent hemostatic properties as a result of high absorption by hemoglobin and particularly by received

October 6, 2015

accepted

December 11, 2015

published online

March 4, 2016
DOI http://dx.doi.org/

10.1055/s-0036-1579741. ISSN 1809-9777.
Copyright $(2016$ by Thieme Publicações License terms Ltda, Rio de Janeiro, Brazil

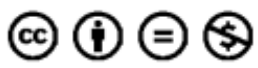


oxyhemoglobin. It is also absorbed by water, but less so than the $\mathrm{CO}_{2}$ laser. ${ }^{5}$ Furthermore it is portable, small, relatively inexpensive, and simple to use. It also has stable power output, long lifetime, and low installation and maintenance costs. ${ }^{2,6}$ Moreover, the diode laser is delivered down by a fine glass fiber that allows the surgeon to hold it in a pencil-like holder for accurate manipulation. ${ }^{2}$ The fiber guidance system tip can be angled, which allows access to areas that are difficult to handle with the $\mathrm{CO}^{2}$ laser. $^{7}$ As a result, the use of diode laser in EMS has increased in recent years. ${ }^{8}$ Nonetheless, the ideal parameters of diode laser in EMS and longterm results remain unclear. Therefore, we conducted a systematic review to clarify the use of diode laser in laryngeal diseases and outcomes shown so far.

\section{Methods}

A systematic search was performed in PubMed, Cochrane Library, Ovid, Web of Science, and Scielo databases. Search terms and Boolean operators used were "larynx" OR "glottic" OR "airway" OR "laryngeal surgery" OR "vocal fold” AND "diode laser." We only included publications in English or Spanish languages. The final search was performed on September $28^{\text {th }}, 2015$. We screened titles and abstracts for relevance and relevant articles for assessment. Reference lists were manually searched for further relevant articles.

We considered all studies relating to human laryngeal pathologies (from superior edge of epiglottis to inferior edge of cricoid cartilage). We only included studies that provided information on patient and lesion characteristics, treatment (diode laser's parameters used in surgery - at least two items described among wavelength, fiber diameter, output power, frequency, wave radiation, and contact mode), and outcomes related to the laser surgery performed. Outcomes could be "cure of the initial pathology," "need of complementary operation," "recurrence of the lesion," or even "complications or adverse/side effects." Studies were excluded if they consisted of less than two subjects or case report. Patients with tracheal disease were not included. Finally, studies that described the use of diode laser with non-surgical intent were excluded.

We collated data from included studies using an Excel (Microsoft, Redmond, Washington) spreadsheet. Specifically, data on sample demographics and clinical characteristics, sample size, diode laser parameters used, duration of follow-up, main outcome findings, and complications were extracted from each study. Article authors were contacted directly to obtain further information in cases of incomplete reported data.

The internal validity of included studies was low overall. We identified no randomized clinical trial and only two experimental controlled studies (not randomized) were included.

\section{Results}

Our search strategy yielded a total of 284 articles (including duplicates). By screening the titles alone, 234 articles could be excluded, as they were either review articles, obviously not relating to the use of diode laser in larynx, or clearly not eligible for inclusion (for example, studies looking at diode laser in animals). This left 50 abstracts, of which 36 were duplicate. After reading the abstracts, one was removed due to its focus on endobronchial diseases. Then, the 13 eligible articles were full-text assessed, but two more were excluded due to failure to meet eligibility criteria (one that did not describe the laser parameters used at one single surgery and another that included patients with lesions outside the larynx). This left 11 articles appropriate for inclusion in the review. We manually searched reference lists for further relevant articles, but none was eligible (-Fig. $\mathbf{1}$ ).

The 11 studies selected for inclusion were published between 2003 and 2014 and originated from 5 different countries. Two studies were experimental controlled but not randomized ${ }^{8,9}$ and another one was a prospective experimental uncontrolled study. ${ }^{7}$ The other studies comprised of 8 retrospective reviews. ${ }^{2,3,5,6,10-13}$ We found no randomized controlled trial or multicenter trials.

A total of 357 subjects made up the study population from the 11 included studies. The average number of participants per study was 32.45 (range: 8-72). - Table 1 details the characteristics of the study population. The laryngeal pathologies included were suprastomal granuloma, laryngomalacia, ventricular dysphonia, vocal polyp, glottic web, papillomas, glottic carcinoma, bilateral cord palsy, subglottic cysts, subglottic stenosis, and subglottic hemangioma/lynfangioma.

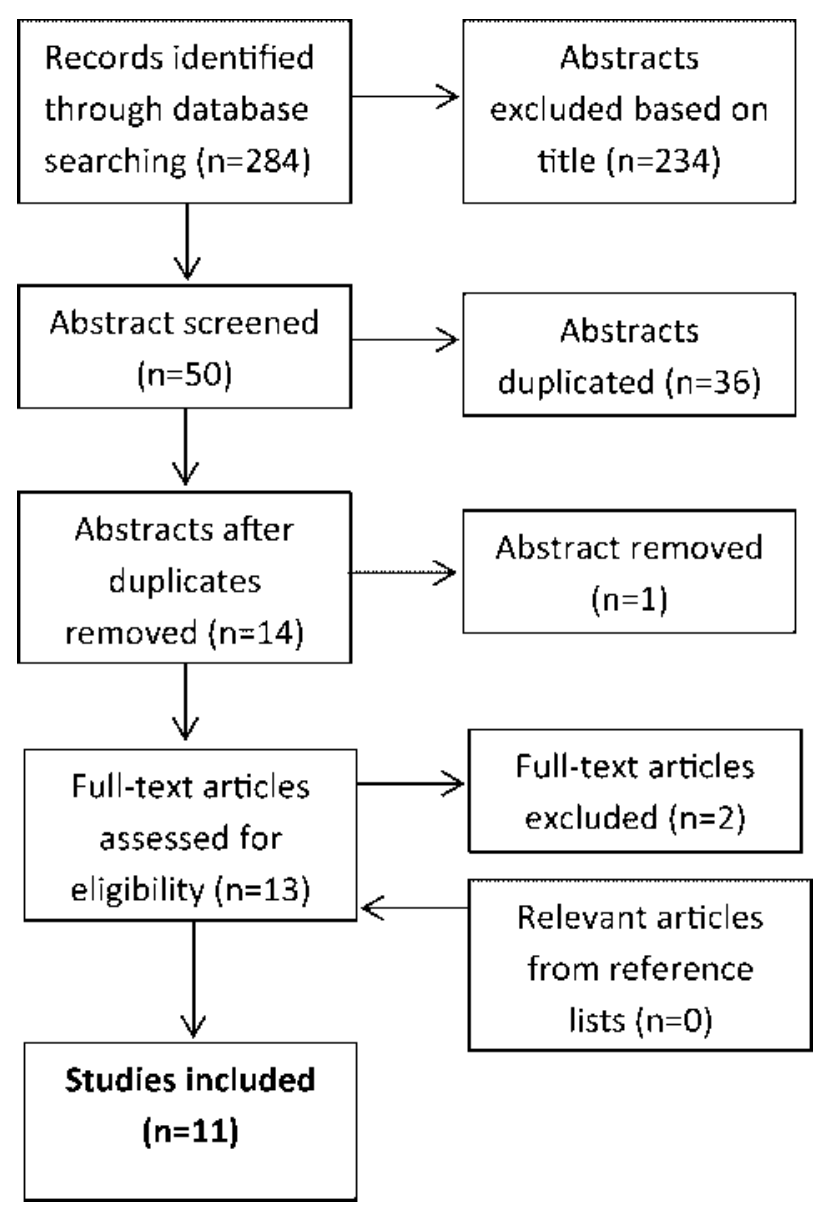

Fig. 1 Diagram of eligibility criteria. 


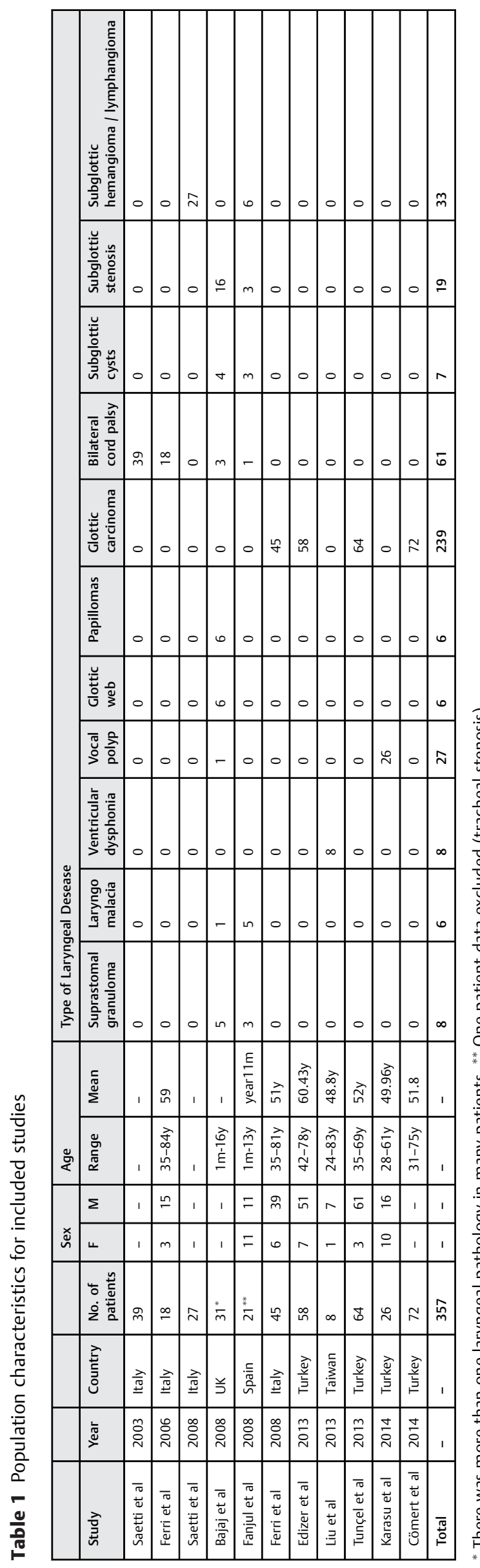

Intervention included diode laser surgery performed in various combinations of parameters between wavelength, fiber diameter, output power, frequency, wave radiation and contact mode, as illustrated in - Table $\mathbf{2}$. The preferred wavelength changed from $810 \mathrm{~nm}$ to $980 \mathrm{~nm}$ since 2013. The minor fiber diameter described was $300 \mu \mathrm{m}$ and the isolated major one was $1400 \mu \mathrm{m}$. The output power varied from $3 \mathrm{~W}$ to $60 \mathrm{~W}$. All authors with available data opted for the direct contact of the fiber to the tissue as well as the continuous mode of energy.

Length of follow-up was variable among the studies, ranging from two to 86 months. A summary of the main findings of each study is illustrated in - Table 3.

Five of 11 authors (46\%) declared to have experienced no complications or side effects by the use of the diode laser. Granulation and posterior synechia were described related to treatment of vocal fold paralysis. ${ }^{10}$ Tracheal posterolateral bridge synechia and laser-induced subglottic granuloma related to treatment of subglottic hemangioma/lynfangioma. ${ }^{5}$ Regarding glottic cancer surgeries, no authors reported edema requiring tracheostomy. Intraoperatively, thyroid cartilage exposure was described and laser-induced fire occurred due to thermal injury of the laser on the intubation tube. Two patients developed cutaneous emphysema that resolved in one day without intervention. ${ }^{12}$ In the postoperative period, synechia and granuloma formation was reported. ${ }^{7}$ Some rare side effects were infection, foul smelling halitosis (in whom relatively more extended laser surgery was performed), laryngeal stenosis, ${ }^{12}$ hemorrhage, and fistula formation. ${ }^{7}$

\section{Discussion}

Carbon dioxide laser has been predominantly used since the introduction of laser surgery. However, it has some limitations, such as increased cost and difficulty in the management of deep and curved areas. In addition, it has short penetration in tissues (0.1-0.3 $\mathrm{mm}$ on average), which reduces effective sealing of vessels (it coagulates vessels of calibers smaller than $0.5 \mathrm{~mm}$ ), thus, increasing bleeding during surgery. ${ }^{3,4}$ The diode laser emits wavelengths that are absorbed predominantly by hemoglobin and melanin (near infrared spectrum). The penetration depth depends on the concentration of these chromophores and, generally, it reaches $0.3-1.0 \mathrm{~mm}$ in diode laser application, which makes it ideal for photocoagulation. ${ }^{4,6,14}$ In conformity to that, some authors advocate that the diode laser $\sim 3-5 \mathrm{~W}$ allows thermal coagulation that had been unimaginable with the $\mathrm{CO}_{2}$ laser. ${ }^{10}$ All of these characteristics, according to some authors, confer on diode laser a surgical precision only slightly inferior to the $\mathrm{CO}_{2}$ laser one, but with a superior coagulation capability for treating laryngeal vascular lesions. ${ }^{5}$ Compared with other devices, diode laser also appears to be more precise and less invasive. For instance, the cutting precision of the NdYAG $(1064 \mathrm{~nm})$ is considerably lower, and the instrument also led to greater immediate and deferred inflammatory damage due to thermal diffusion (high penetration capacity of up to $4 \mathrm{~mm}$ ). ${ }^{3,10}$

Furthermore, the diode laser's beam, in contrast to the carbon dioxide laser, is carried by flexible optic fibers that can 
Table 2 Intervention treatment - parameters of diode laser in larynx

\begin{tabular}{|c|c|c|c|c|c|c|c|c|}
\hline \multirow[b]{2}{*}{ Study } & \multirow[b]{2}{*}{ Year } & \multirow[b]{2}{*}{$\begin{array}{l}\text { No. of } \\
\text { patients }\end{array}$} & \multicolumn{6}{|l|}{ Parameters } \\
\hline & & & $\begin{array}{l}\text { Wavelength } \\
(\mathrm{nm})\end{array}$ & $\begin{array}{l}\text { Fiber } \\
\text { diameter } \\
(\mu \mathrm{m})\end{array}$ & $\begin{array}{l}\text { Output } \\
\text { power (W) }\end{array}$ & $\begin{array}{l}\text { Frequency } \\
(\mathrm{Hz})\end{array}$ & $\begin{array}{l}\text { Wave } \\
\text { Radiation }\end{array}$ & Contact Mode \\
\hline Saetti et al & 2003 & 39 & 810 & $300-600$ & 10 & - & - & Direct contact \\
\hline Ferri et al & 2006 & 18 & 810 & 600 & 10 & - & Continuous & Direct contact \\
\hline Saetti et al & 2008 & 27 & 810 & $300-600$ & $5-8$ & - & $\begin{array}{l}\text { Continuous/Low } \\
\text { frequency } \\
\text { pulsation }\end{array}$ & - \\
\hline Bajaj et al & 2008 & 31 & 805 & 400 & $3-5$ & - & Continuous & Direct contact \\
\hline Fanjul et al & 2008 & 21 & $820+20$ & $400-600$ & $10-15$ & - & - & Direct contact \\
\hline Ferri et al & 2008 & 45 & 810 & $600-1000$ & $\begin{array}{l}5-60 \\
\text { (mean 30) }\end{array}$ & $60 \mathrm{~Hz}$ & Continuous & Direct contact \\
\hline Edizer et al & 2013 & 58 & - & - & $6-12$ & - & Continuous & - \\
\hline Liu et al & 2013 & 8 & 810 & 1400 & $\max 5$ & - & Continuous & - \\
\hline Tunçel et al & 2013 & 64 & 980 & 400 & $4-9$ & & Continuous & Direct contact \\
\hline Karasu et al & 2014 & 26 & 980 & 400 & $3-5$ & - & Continuous & Direct contact \\
\hline Cömert et al & 2014 & 72 & 980 & 400 & $4-9$ & - & Continuous & Direct contact \\
\hline
\end{tabular}

$-=$ data not available.

be coupled with telescopes permitting access to sites that are difficult to explore with other techniques, such as the subglottic region. ${ }^{5}$ Recently, a $\mathrm{CO}_{2}$ laser beam delivered through a flexible hollow tube has become available that delivers the beam close to the target. ${ }^{15}$ However, the use of diode laser by contact (or extremely close distance) makes it much safer than other laser sources by avoiding damage due to "beam scape" in an open field. ${ }^{5}$

As this review shows, the diode laser can be a useful tool for treatment of different laryngeal pathologies, such as suprastomal granuloma, laryngomalacia, ventricular dysphonia, vocal polyp, glottic web, papilloma, glottic carcinoma, bilateral cord palsy, subglottic cyst, subglottic stenosis, subglottic hemangioma and lymphangioma. In this sense, the laser parameters must be set depending on the goal (vaporization, section or coagulation) and the clinical problem.

With respect to output power, diameter of fiber and wavelength, the articles selected in this review presented different arrangements for diode laser. This reveals the lack of standardization in setting the best parameters of diode laser for laryngeal surgery. Although these parameters may influence collateral tissue damage, the studies are difficult to compare, based on the following concepts of laser's physics. Power, given in watts $(\mathrm{W})$, measures the rate that the laser beam transmits. Beam energy, measured in joules $(\mathrm{J})$, can be found by multiplying the power $(\mathrm{W})$ by exposure time (in seconds). Power density, also called irradiance or spot brightness, determines the rate at which tissue is removed at the surgical site, measured in units of watts per square centimeter $(\mathrm{W} / \mathrm{cm} 2)$. Fluence is a key parameter once it combines previously mentioned parameters of power density and dosage, and is measured in units of joules per square centimeter $(\mathrm{J} / \mathrm{cm} 2)$. It is important to understand this to provide minimal damage to tissues adjacent to the incision site, as using a higher pulse power for a shorter period of time results in less tissue damage than using lower power for a longer period of time. Tissue damage is dependent upon the tissue absorption coefficient, the wavelength of the laser, power density, and the length of time over which the energy is delivered, which is largely technique dependent. ${ }^{16}$ These data were not provided by any of the included studies.

An additional property that can affect the severity of tissue damage is thermal relaxation time, the time required for tissue to lose $50 \%$ of its heat through diffusion. ${ }^{17}$ One can decrease tissue damage by allowing heated tissue to cool during a procedure. However, it could be accomplished through the use of a pulsed laser, spacing out laser impact, even for a continuous incision, that decreases thermal damage by allowing time for the tissue to cool between impacts. ${ }^{16}$ In contrast, the authors of studies included in this review opted for the continuous wave radiation, some followed by manual tissue cooling.

Special attention must be given to laser surgery for the treatment of glottic cancer, once it can be more cost-effective than 'cold surgery' when managing laryngeal tumors, as they allow briefer hospital stays and shorter wound recovery periods. ${ }^{18}$ The $\mathrm{CO}_{2}$ laser surgery was presented as one of the most accepted treatment options of early glottic carcinoma due to its high local control rates, low morbidity, and good postoperative voice quality. ${ }^{19}$ However, if the surgeon has difficulty in managing laryngeal anterior commissure tumors, he or she is encouraged by some authors to avoid $\mathrm{CO}_{2}$ laser microsurgery. Alternatively, the $810 \mathrm{~nm}$ diode laser has been recently used for the treatment of glottic tumors and may allow better exposure and resection of tumors in the anterior commissure. The first to establish long-term results for glottic cancer treatment were Ferri et al, in 2008. However, it seems that diode laser has not been well accepted worldwide for 
Table 3 Main outcome findings

\begin{tabular}{|c|c|c|c|c|c|}
\hline Study & Year & $\begin{array}{l}\text { Follow-up } \\
\text { Range } \\
\text { (Mean) }\end{array}$ & $\begin{array}{l}\text { Type of laryngeal } \\
\text { disease }\end{array}$ & Main outcome findings & Complications \\
\hline Saetti et al & 2003 & $(6 \mathrm{~m})$ & $\begin{array}{l}\text { bilateral vocal cord } \\
\text { palsy }\end{array}$ & $\begin{array}{l}\text { Good (no exertional dyspnea after } \\
\text { physical effort), sufficient } \\
\text { (no resting dyspnea and normal } \\
\text { everyday activity) results, and } \\
\text { decanulation of previously } \\
\text { tracheotomised patients were } \\
\text { obtained from all patients after } \\
\text { one or two procedures. }\end{array}$ & $\begin{array}{l}\text { No significant intraoperative } \\
\text { complications occurred. The } \\
\text { only complications observed, } \\
\text { in the post-operative period, } \\
\text { were } 3 \text { cases of granulation, } \\
\text { which was removed on an } \\
\text { outpatient basis, and } 1 \text { case of } \\
\text { posterior synechia that } \\
\text { required no further treatment. }\end{array}$ \\
\hline Ferri et al & 2006 & $(20 m)$ & $\begin{array}{l}\text { bilateral vocal cord } \\
\text { palsy }\end{array}$ & $\begin{array}{l}\text { The improvement in respiratory } \\
\text { function was evident already } \\
\text { between the first hours, stabilizing } \\
\text { on the first week. By the second } \\
\text { day, all patients could eat without } \\
\text { aspiration. The nine patients with } \\
\text { tracheostomy cannula previous } \\
\text { from the endoscopic surgery were } \\
\text { decannulated in a maximum of } \\
\text { sixty days after surgery. }\end{array}$ & None \\
\hline Saetti et al & 2008 & - & $\begin{array}{l}\text { Subglottic heman- } \\
\text { gioma / } \\
\text { lymphangioma }\end{array}$ & $\begin{array}{l}\text { Diode laser was the primary treat- } \\
\text { ment in } 22 \text { patients, showing a } \\
\text { success rate of } 95 \% \text { ( } 21 \text { of } 22 \text { ). One } \\
\text { children experienced a recurrence } \\
\text { of stridor after systemic steroids } \\
\text { therapy and required diode laser } \\
\text { vaporization. The same secondary } \\
\text { laser treatment was used in } 2 \text { cases } \\
\text { in which a progression of the tumor } \\
\text { with worsening of respiratory } \\
\text { symptoms was recorded notwith- } \\
\text { standing steroid treatment. Other } \\
2 \text { patients that underwent intrale- } \\
\text { sional corticosteroid injection } \\
\text { underwent secondary laser } \\
\text { treatment. }\end{array}$ & $\begin{array}{l}\text { No early complications (intra- } \\
\text { operative or postoperative } \\
\text { bleeding). One tracheal } \\
\text { posterolateral bridge synechia } \\
\text { (resolved after treatment with } \\
\text { a diode laser section); and one } \\
\text { laser-induced subglottic } \\
\text { granuloma - successfully } \\
\text { removed by means of } \\
\text { videoscopic forceps. }\end{array}$ \\
\hline Bajaj ey al & 2008 & $6 m-3 y$ & $\begin{array}{l}\text { Mainly subglottic } \\
\text { stenosis, but } \\
\text { included various } \\
\text { (8) diagnosis }\end{array}$ & $\begin{array}{l}\text { 19/31 ( } 61.3 \%) \text { patients have been } \\
\text { cured of their initial pathologies } \\
\text { and were not under further review. } \\
\text { Another } 9 / 31 \text { ( } 29.0 \%) \text { had to } \\
\text { undergo different operations. The } \\
\text { remaining } 3 / 31(9.6 \%) \text { (all three } \\
\text { recurrent respiratory papillomato- } \\
\text { sis) are undergoing repeated laser } \\
\text { and other adjuvant treatments. }\end{array}$ & None \\
\hline Fanjul et al & 2008 & - & $\begin{array}{l}\text { Various (5) } \\
\text { diagnosis }\end{array}$ & $\begin{array}{l}\text { The saccular lesions, mucous } \\
\text { membranes, granulomas and } \\
\text { arytenoid abnormalities resolved } \\
\text { by the exclusive application of laser } \\
\text { ( } 78.6 \% \text { with a single procedure). In } \\
\text { other situations, such as vascular } \\
\text { anomalies (hemangiomas and } \\
\text { lymphangiomas) and subglottic } \\
\text { stenosis, we have pointed to other } \\
\text { treatments (surgical and medical in } \\
87.5 \% \text { and } 12.5 \% \text { respectively) for } \\
\text { resolution. }\end{array}$ & None \\
\hline
\end{tabular}


Table 3 (Continued)

\begin{tabular}{|c|c|c|c|c|c|}
\hline Study & Year & $\begin{array}{l}\text { Follow-up } \\
\text { Range } \\
\text { (Mean) }\end{array}$ & $\begin{array}{l}\text { Type of laryngeal } \\
\text { disease }\end{array}$ & Main outcome findings & Complications \\
\hline Ferri et al & 2008 & $\begin{array}{l}24-86 m \\
(36 m)\end{array}$ & Glottic carcinoma & $\begin{array}{l}\text { There were } 5 \text { recurrences ( } 11.1 \%) \text { : } \\
4 \text { local }(8.9 \%) \text {, in which } 3 \text { were } \\
\text { salvaged, and } 1(2.2 \%) \text { regional } \\
\text { (N2a). Three patients (6.7\%) } \\
\text { developed second primary cancers } \\
\text { on the opposite cord after a mean } \\
\text { of } 18 \text { months (range, } 9-47 \\
\text { months) ( } 1 \text { was salvaged with total } \\
\text { laryngectomy, } 1 \text { with repeat laser } \\
\text { surgery and RT, } 1 \text { with partial } \\
\text { laryngectomy with open surgery). }\end{array}$ & $\begin{array}{l}\text { No major complications were } \\
\text { observed. The development of } \\
\text { small granulomas was uncom- } \\
\text { mon (6.6\%) and they usually } \\
\text { resorbed within a few weeks } \\
\text { without any further surgery. }\end{array}$ \\
\hline Edizer et al & 2013 & $\begin{array}{l}24-48 m \\
(35.3 m)\end{array}$ & Glottic carcinoma & $\begin{array}{l}\text { The involvement of the anterior- } \\
\text { commissure was present in } 13 \\
\text { ( } 22 \% \text { ) of the patients. During the } \\
\text { follow-up period, in } 8 \text { of these } \\
\text { patients, granulation tissue or } \\
\text { synechia developed at the anterior } \\
\text { part of the larynx. Local recurrence } \\
\text { was encountered in } 5 \text { ( } 8 \% \text { ) patients } \\
\text { ( } 1 \text { case with T1a, } 3 \text { with T } 2 \text { and one } \\
\text { patient with T3 primary tumor at } \\
\text { the initial presentation). }\end{array}$ & $\begin{array}{l}\text { Thyroid cartilage exposure in } 1 \\
\text { patient. Intraoperative laser- } \\
\text { induced fire occurred due to } \\
\text { thermal injury of the laser on } \\
\text { the intubation tube in } 1 \\
\text { patient. Two patients devel- } \\
\text { oped cutaneous emphysema } \\
\text { which resolved in one day } \\
\text { without intervention. In the } \\
\text { postoperative period, infection } \\
\text { and foul smelling halitosis } \\
\text { developed in } 5 \text { patients in } \\
\text { whom relatively more extend- } \\
\text { ed laser surgery was per- } \\
\text { formed. Laryngeal stenosis was } \\
\text { seen in } 2 \text { patients. }\end{array}$ \\
\hline Liu et al & 2013 & $\begin{array}{l}13-58 \mathrm{~m} \\
(40.8 \mathrm{~m})\end{array}$ & $\begin{array}{l}\text { Ventricular } \\
\text { dysphonia }\end{array}$ & $\begin{array}{l}\text { No neo-growth of false folds was } \\
\text { noted. (OBS: the role of diode laser } \\
\text { was not improving the vocal quality } \\
\text { but offering better visualization of } \\
\text { true vocal behavior). }\end{array}$ & None \\
\hline Tunçel et al & 2013 & $\begin{array}{l}15-32 \mathrm{~m} \\
(20.4 \mathrm{~m})\end{array}$ & Glottic carcinoma & $\begin{array}{l}\text { Local control and larynx preserva- } \\
\text { tion rates were } 93.8 \% \text { and } 100 \% \text {, } \\
\text { respectively. There were } 4 \text { recur- } \\
\text { rences ( } 6.2 \%) \text {, all within the first } \\
15 \text { months after treatment (range, } \\
10-15 \text { months). }\end{array}$ & $\begin{array}{l}\text { Fistula formation (1.5\%), hem- } \\
\text { orrhage ( } 1.5 \%) \text {, and massive } \\
\text { recurrent granuloma forma- } \\
\text { tion ( } 1.5 \%) \text { were the main } \\
\text { complications. Minor compli- } \\
\text { cations, including synechia and } \\
\text { granuloma, were seen in } 20.2 \% \\
\text { of the patients. Four ( } 6.2 \%) \\
\text { patients had synechia, and } 25 \% \\
\text { of these patients needed } \\
\text { surgical treatment. Nine ( } 14 \%) \\
\text { patients had mild granuloma } \\
\text { formation. Almost all compli- } \\
\text { cations were related to anteri- } \\
\text { or commissure surgery. }\end{array}$ \\
\hline Karasu et al & 2014 & $2 m$ & Vocal polyp & $\begin{array}{l}\text { Postoperatively, in terms of voice } \\
\text { handicap index and voice analyses, } \\
\text { no statistically significant differen- } \\
\text { ces were found between the diode } \\
\text { laser group and cold knife group } \\
\text { and both improved significantly } \\
\text { from baseline measurement } \\
(p<0.001)\end{array}$ & None \\
\hline Cömert et al & 2014 & $\begin{array}{l}12-37 m \\
(29.3 \mathrm{~m})\end{array}$ & Glottic carcinoma & $\begin{array}{l}\text { Initial control of the primary lesions } \\
\text { was achieved in } 97.4 \%(n=38) \text { for } \\
\text { T1 and } 87.8 \%(n=29) \text { for T2 } \\
\text { patients. }\end{array}$ & $\begin{array}{l}5 \text { patients }(6.9 \%) \text { developed a } \\
\text { locoregional recurrence. }\end{array}$ \\
\hline
\end{tabular}

Abbreviations: $\mathrm{m}$, months; $\mathrm{y}$, years. 
laryngeal surgery, as our review shows a gap of publications between 2008 and 2013. According to that, we speculate that most institutions continued using the $\mathrm{CO}_{2}$ laser, due to doctors' familiarity with its use, capabilities, and limitations. $^{9,16}$ On the other hand, the $980 \mathrm{~nm}$ diode laser is a new technology, and has been reported for the treatment of early glottic tumors and vocal fold polyps since $2013 .^{7-9}$ The main difference between these two diode laser wavelengths is their distinct absorption by the vocal fold, as the $980 \mathrm{~nm}$ is slightly more absorbed by water than the $810 \mathrm{~nm}$ one. The three studies that used the $980 \mathrm{~nm}$ diode laser were among those with a better design in our review. Two referred to controlled trials $^{8,9}$ and the other was an uncontrolled trial. ${ }^{7}$ These studies showed good efficacy results and low rates of major complications.

Concerning functional outcomes, as measured by the voice handicap index (VHI), Karasu et al showed good results of $980 \mathrm{~nm}$ diode laser in treating vocal fold polyps. ${ }^{8}$ A comparison between diode and $\mathrm{CO}_{2}$ laser could be quite useful to highlight the differences and compare the results, especially the functional ones. The ideal comparison to assess both types of lasers would involve a randomized clinical trial with these two techniques, which is nonexistent in the literature. Even though the comparison of non-controlled studies of two different techniques can involve bias, in -Table $\mathbf{4}$ we show some results of some authoritative works related to the use of $\mathrm{CO} 2$ laser for larynx surgery in the literature in similar conditions to those with diode laser on our review, so that the reader can grossly compare with - Table 3 . $^{17,20-23}$

Regarding safety issues, five authors reported no complications or side effects by the use of the diode laser, but none of these studies was related to glottic cancer or extensive procedures. The major complications were related to more extensive surgeries and with anterior commissure involvement. ${ }^{7}$ Possibly the most feared complication is the endotracheal tube airway fire, which can be catastrophic or even fatal. ${ }^{24}$ To avoid that, some authors use reinforced tubes for laser surgery ${ }^{6}$ while others described the tube being inflated

Table 4 Results of comparable studies of $\mathrm{CO}_{2}$ laser in larynx surgery

\begin{tabular}{|c|c|c|c|c|c|c|}
\hline $\begin{array}{l}\text { Study / } \\
\text { Country }\end{array}$ & Year & $\begin{array}{l}\text { Follow-up } \\
\text { Range } \\
\text { (Mean) }\end{array}$ & $\begin{array}{l}\text { Type of } \\
\text { laryngeal } \\
\text { disease }\end{array}$ & $\begin{array}{l}\text { No. of } \\
\text { patients }\end{array}$ & Main outcome findings & Complications \\
\hline $\begin{array}{l}\text { Bajaj et al / } \\
\text { UK }\end{array}$ & 2009 & $3 m-4 y(28 m)$ & $\begin{array}{l}\text { Bilateral vocal } \\
\text { cord palsy }\end{array}$ & 9 & $\begin{array}{l}\text { None of the patients required post- } \\
\text { operative tracheostomy, and all } \\
\text { three patients with a previous } \\
\text { tracheostomy were successfully } \\
\text { decannulated within one month of } \\
\text { their operation. }\end{array}$ & $\begin{array}{l}\text { There was a single complication in this } \\
\text { study group, in a patient who developed } \\
\text { breathing difficulty } 48 \text { hours after the } \\
\text { procedure and had to be readmitted. He } \\
\text { improved with antibiotics and steroids, } \\
\text { and was observed for any worsening of } \\
\text { dyspnea for six days in hospital. }\end{array}$ \\
\hline $\begin{array}{l}\text { Özdemir et al / } \\
\text { Turkey }\end{array}$ & 2013 & $\begin{array}{l}4-120 m \\
(40 m)\end{array}$ & $\begin{array}{l}\text { Bilateral vocal } \\
\text { cord palsy }\end{array}$ & 66 & $\begin{array}{l}\text { For } 58 \text { patients ( } 88 \% \text { ), airway } \\
\text { restoration was maintained by per- } \\
\text { forming a successful } 1 \text {-step surgical } \\
\text { procedure, } 7 \text { patients ( } 11 \% \text { ) had } \\
\text { vocal edema in the postoperative } \\
\text { hospitalization period. Medical } \\
\text { treatment with oral corticosteroids } \\
\text { corrected edema in } 3 \text { patients. }\end{array}$ & $\begin{array}{l}\text { Tracheotomy was performed on } 4 \text { (6\%) } \\
\text { patients postoperatively because of dys- } \\
\text { pnea caused by vocal edema; } 12 \text { patients } \\
\text { ( } 18 \% \text { ) required a second operation, } \\
\text { including the } 4 \text { who underwent } \\
\text { postoperative tracheotomies. Four } \\
\text { patients (6\%) required a revision proce- } \\
\text { dure because of shortness of breath } \\
\text { caused by granulomas on the operated- } \\
\text { on side. In addition, } 4 \text { patients (6\%) } \\
\text { underwent contralateral posterior } \\
\text { cordotomy because of an insufficient } \\
\text { airway in a second operation. }\end{array}$ \\
\hline $\begin{array}{l}\text { Bitar et al / } \\
\text { USA }\end{array}$ & 2005 & $\begin{array}{l}12-69 m \\
(33 m)\end{array}$ & $\begin{array}{l}\text { Subglottic } \\
\text { hemangioma }\end{array}$ & 81 & $\begin{array}{l}\text { Thirty-six patients receiving } \mathrm{CO}_{2} \\
\text { laser combined with systemic } \\
\text { corticosteroids had } 80.6 \% \text { success } \\
\text { rate. }\end{array}$ & $\begin{array}{l}\text { Complications in all patients receiving } \\
\mathrm{CO}_{2} \text { laser included subglottic stenosis } \\
(5.5 \%) \text {, web formation, pneumothorax, } \\
\text { and interarytenoid scarring. Used on } 58 \\
\text { tracheotomized patients, the } \mathrm{CO}_{2} \text { laser } \\
\text { resulted in a decrease in the mean } \\
\text { cannulation duration from } 21 \text { to } 7.3 \\
\text { months. }\end{array}$ \\
\hline $\begin{array}{l}\text { Canis et al / } \\
\text { Germany }\end{array}$ & 2015 & $\begin{array}{l}0.03-236.3 \mathrm{~m} \\
(78.2 \mathrm{~m})\end{array}$ & Glottic cancer & 404 & $\begin{array}{l}\text { Recurrence developed in } 56 \\
\text { patients ( } 14.4 \% \text { ). Site of recurrence } \\
\text { was local in } 50 \text { patients and } \\
\text { locoregional in } 6 \text { patients. Nineteen } \\
\text { patients experienced a second and } 7 \\
\text { patients a third recurrence. A total } \\
\text { laryngectomy was required in } 11 \\
\text { patients for salvage after primary } \\
\text { laser microsurgical resection. }\end{array}$ & $\begin{array}{l}\text { The overall complication rate was } 1 \% \\
\text { ( } 4 \text { of } 404) \text { and included airway obstruc- } \\
\text { tion in } 2 \text { patients }(0.5 \%) \text {, which were } \\
\text { successfully treated with corticosteroids } \\
\text { and postoperative bleeding that required } \\
\text { microlaryngoscopical electrocoagula- } \\
\text { tion in } 2 \text { patients }(0.5 \%) \text {. Sixty-six } \\
\text { patients ( } 15.1 \%) \text { underwent a second } \\
\text { microlaryngoscopy for removal of gran- } \\
\text { ulation tissue. No patient needed a } \\
\text { tracheostomy or nasogastric feeding } \\
\text { tube. }\end{array}$ \\
\hline $\begin{array}{l}\text { Benninger / } \\
\text { USA }\end{array}$ & 2000 & $5-12 w$ & Benign lesions & 37 & $\begin{array}{l}\text { Significant improvements in video- } \\
\text { stroboscopic parameters were } \\
\text { found over time. }\end{array}$ & None \\
\hline
\end{tabular}

Abbreviations: m, months; y, years. 
using saline with methylene blue dye, so that a puncture could be immediately diagnosed. ${ }^{7}$

This review highlights the lack of good evidence for the use of diode laser in laryngeal surgery. Furthermore, it is clear that there is wide variation in how it is used around the world. The $980 \mathrm{~nm}$ diode laser seems to be a promising laser device, so we would expect that, as experience increases, it will be more extensively used as well as new lasers wavelengths can emerge. ${ }^{8}$

\section{Final Comments}

Despite the heterogeneous populations, varied inclusion criteria, and retrospective designs of most the studies considered in this review, they do provide useful information to the surgeon who intends to use diode laser for transoral laser microsurgery. The evidence from recent studies suggests an improvement in diode laser technology (especially the $980 \mathrm{~nm}$ wavelength). Further long-term multicenter prospective research is needed, although the findings of this review suggest that diode laser is a useful tool that should be considered in laryngeal surgeries.

\section{References}

1 Strong MS, Jako GJ. Laser surgery in the larynx. Early clinical experience with continuous CO 2 laser. Ann Otol Rhinol Laryngol 1972;81(6):791-798

2 Bajaj Y, Pegg D, Gunasekaran S, Knight LC. Diode laser for paediatric airway procedures: a useful tool. Int J Clin Pract 2010;64(1):51-54

3 Fanjul M, García-Casillas MA, Parente A, et al. Utilización del láser diodo en la vía aérea pediátrica. Cir Pediatr 2008;21(2):79-83

4 Vilaseca I, Bernal-Sprekelsen M, Luis Blanch J. Transoral laser microsurgery for T3 laryngeal tumors: Prognostic factors. Head Neck 2010;32(7):929-938

5 Saetti R, Silvestrini M, Cutrone C, Narne S. Treatment of congenital subglottic hemangiomas: our experience compared with reports in the literature. Arch Otolaryngol Head Neck Surg 2008;134(8): 848-851

6 Ferri E, Armato E. Diode laser microsurgery for treatment of Tis and T1 glottic carcinomas. Am J Otolaryngol 2008;29(2):101-105

7 Tunçel U, Cömert E. Preliminary results of diode laser surgery for early glottic cancer. Otolaryngol Head Neck Surg 2013;149(3):445-450
8 Karasu MF, Gundogdu R, Cagli S, et al. Comparison of effects on voice of diode laser and cold knife microlaryngology techniques for vocal fold polyps. J Voice 2014;28(3):387-392

9 Cömert E, Tunçel Ü, Dizman A, Güney YY. Comparison of early oncological results of diode laser surgery with radiotherapy for early glottic carcinoma. Otolaryngol Head Neck Surg 2014;150(5):818-823

10 Saetti R, Silvestrini M, Galiotto M, Derosas F, Narne S. Contact laser surgery in treatment of vocal fold paralysis. Acta Otorhinolaryngol Ital 2003;23(1):33-37

11 Ferri E, García Purriños FJ. [Diode laser surgery in the endoscopic treatment of laryngeal paralysis]. Acta Otorrinolaringol Esp 2006; 57(6):270-274

12 Edizer DT, Cansız H. Transoral Laser Microsurgery for Glottic Cancers - Complications and Importance of the Anterior Commissure Involvement. Istanb Med J. 2013;14:12-15

13 Liu S-C, Lin D-S, Su W-F. The role of diode laser in the treatment of ventricular dysphonia. J Voice 2013;27(2):250-254

14 Sullins KE. Diode laser and endoscopic laser surgery. Vet Clin North Am Small Anim Pract 2002;32(3):639-648, vii vii

15 Rubinstein M, Armstrong WB. Transoral laser microsurgery for laryngeal cancer: a primer and review of laser dosimetry. Lasers Med Sci 2011;26(1):113-124

16 Yan Y, Olszewski AE, Hoffman MR, et al. Use of lasers in laryngeal surgery. J Voice 2010;24(1):102-109

17 Benninger MS. Microdissection or microspot $\mathrm{CO} 2$ laser for limited vocal fold benign lesions: a prospective randomized trial. Laryngoscope 2000;110(2 Pt 2, Suppl 92)1-17

18 Xu W, Han D, Hou L, Zhang L, Yu Z, Huang Z. Voice function following $\mathrm{CO} 2$ laser microsurgery for precancerous and earlystage glottic carcinoma. Acta Otolaryngol 2007;127(6):637-641

19 Lucioni M, Marioni G, Bertolin A, Giacomelli L, Rizzotto G. Glottic laser surgery: outcomes according to 2007 ELS classification. Eur Arch Otorhinolaryngol 2011;268(12):1771-1778

20 Bajaj Y, Sethi N, Shayah A, et al. Vocal fold paralysis: role of bilateral transverse cordotomy. J Laryngol Otol 2009;123(12): 1348-1351

21 Özdemir S, Tuncer Ü, Tarkan Ö, Kara K, Sürmelioğlu Ö. Carbon dioxide laser endoscopic posterior cordotomy technique for bilateral abductor vocal cord paralysis: a 15-year experience. JAMA Otolaryngol Head Neck Surg 2013;139(4):401-404

22 Bitar MA, Moukarbel RV, Zalzal GH. Management of congenital subglottic hemangioma: trends and success over the past 17 years. Otolaryngol Head Neck Surg 2005;132(2):226-231

23 Canis M, Ihler F, Martin A, Matthias C, Steiner W. Transoral laser microsurgery for T1a glottic cancer: review of 404 cases. Head Neck 2015;37(6):889-895

24 Dhar P, Malik A. Anesthesia for laser surgery in ENT and the various ventilatory techniques. Trends Anaesth Crit Care. 2011;1:60-66 